IZA DP No. 10199

Barriers to Skill Acquisition:

Evidence from English Training in India

Tarun Jain

Pushkar Maitra

Subha Mani

September 2016 


\title{
Barriers to Skill Acquisition: Evidence from English Training in India
}

\author{
Tarun Jain \\ Indian School of Business \\ Pushkar Maitra \\ Monash University \\ Subha Mani \\ Fordham University \\ and IZA
}

\section{Discussion Paper No. 10199 \\ September 2016}

\author{
IZA \\ P.O. Box 7240 \\ 53072 Bonn \\ Germany \\ Phone: +49-228-3894-0 \\ Fax: +49-228-3894-180 \\ E-mail: iza@iza.org
}

Any opinions expressed here are those of the author(s) and not those of IZA. Research published in this series may include views on policy, but the institute itself takes no institutional policy positions. The IZA research network is committed to the IZA Guiding Principles of Research Integrity.

The Institute for the Study of Labor (IZA) in Bonn is a local and virtual international research center and a place of communication between science, politics and business. IZA is an independent nonprofit organization supported by Deutsche Post Foundation. The center is associated with the University of Bonn and offers a stimulating research environment through its international network, workshops and conferences, data service, project support, research visits and doctoral program. IZA engages in (i) original and internationally competitive research in all fields of labor economics, (ii) development of policy concepts, and (iii) dissemination of research results and concepts to the interested public.

IZA Discussion Papers often represent preliminary work and are circulated to encourage discussion. Citation of such a paper should account for its provisional character. A revised version may be available directly from the author. 
IZA Discussion Paper No. 10199

September 2016

\section{ABSTRACT \\ Barriers to Skill Acquisition: Evidence from English Training in India*}

Skill development is increasingly viewed as a way to escape the low education - high unemployment trap in developing countries. Consequently, policy makers in these countries are extensively investing in skill development programs. However, participation and completion rates in many of these programs remains low. This paper investigates factors that prevent individuals from acquiring spoken English, an important skill with potentially high returns in the labor market. Using data from a field experiment in India that subsidizes the cost of learning spoken English, we find that full subsidy (compared to partial or no subsidy) positively effects the probability of participating in a spoken English training program. Conversely, distance to the training center, pre-existing knowledge of spoken English, and past enrollment in a similar course act as significant barriers to take-up. These findings suggest that multidimensional policy solutions are required to overcome the barriers to skill development in developing countries.

JEL Classification: $\quad$ I25, J24, J44

Keywords: skill development, vocational training, spoken English, field experiment, India

Corresponding author:

Subha Mani

Department of Economics

Fordham University

441 East Fordham Road

Dealy Hall, E 520

Bronx, New York 10458

USA

E-mail: smani@fordham.edu

\footnotetext{
* We thank Urvashi Jain, Benston John, Nikita Modi, and Priyanka Sarda for outstanding research assistance and participants at the Australasian Development Economics Workshop for their comments. IRB approval obtained from the Indian School of Business.
} 


\section{Introduction}

The rapid transition from primary to secondary and tertiary sector employment has increased the demand for skilled workers in many developing countries. As a result, policy attention has moved beyond the school with rapid investments in short-term skill development programs (World Bank, 2008). While the returns from focused skill development programs are potentially high, the factors that facilitate or hinder the success of such programs to develop marketable skills are poorly understood. Drawing on the case of spoken English training for students about to enter the whitecollar job market in India, this paper investigates the multi-dimensional constraints that prevent high participation in programs, even those with potentially high economic returns.

A large literature examines the causes and consequences of skill development in the context of developed economies. Summarizing this literature, Card et al. (2010) report that classroom and on-the-job training programs have not been particularly effective, especially in the short run. The constraints to enrollment and participation in skill development programs in developing countries might be very different; for instance, credit constraints might bind more severely in developing countries, or labor markets to match with employers might be poorly developed (Jain and Sarda, 2014). These constraints would both prevent workers who need training from acquiring it, and workers from realizing the value of their training. As a result, the policy space calls for extensive government involvement to promote skill development in developing countries (Ministry of Skill Development and Entrepreneurship, 2015, World Bank, 2008).

English has a unique and critical role in the skills spectrum. English is the third most spoken language in the world with more than 335 million individual speakers. However, just this statistic masks the importance of English in the global economy. English is easily the most international language, spoken most commonly among individuals from different countries. As such, it is the lingua franca of international business and trade. In the past decade, the importance of English in developing countries has increased as millions of jobs that require fluency in spoken English have been off-shored from the developed world (Mankiw and Swagel, 2006). ${ }^{1}$ Additionally, most of

\footnotetext{
${ }^{1}$ These new service sector jobs in the developing world are often associated with higher economic and social returns
} 
the world's advanced knowledge creation and dissemination is in English. For instance, English is the most prominent language of instruction in universities around the world. Simultaneously, most international news is broadcast in English, and it is the most common language used on the internet. Thus, at an individual level, English fluency is a key skill for career success and economic mobility. At a policy level, India's New Education Policy draft emphasized the importance of teaching English as part of the three-language formula in schools (Subramanian, 2016).

Despite the centrality of English and the associated policy enthusiasm, the literature on the value of English language skills in the context of developing countries is small. Using all-India data, Azam et al. (2013) estimate that speaking fluently in English is associated with 32\% higher earnings, that is four times higher than the average economic return to an additional year of schooling. In more state specific studies, Munshi and Rosenzweig (2006) and Chakraborty and Kapur (2016) estimate the returns to attending a school with English (as opposed to the vernacular language) as the medium of instruction. Using primary data on Maharashtrians living in Mumbai, Munshi and Rosenzweig (2006) find that attending an English-medium school increased both women's and men's income by about 25\%. Using data from the National Sample Survey, Chakraborty and Kapur (2016) estimate the impact of a 1983 policy in West Bengal which eliminated English as the medium of instruction in government run primary schools. Simple comparisons of cohorts attending primary school before and after the policy change suggest that Englishmedium schooling raised wages by about $15 \%$ in the 2000s. Similarly, Levinsohn (2007) and Lang and Siniver (2009) also examine the returns to spoken English skills in countries (South Africa and Israel respectively) where it is not the dominant language. ${ }^{2}$

Other papers investigate the economic and non-economic impacts of spoken English language skills among individuals who immigrated to the United States as children, addressing both the ability bias and measurement error bias present in OLS estimate of the returns to spoken English.

\footnotetext{
(Chamarbagwala and Sharma, 2011).

${ }^{2}$ More generally, the literature documents significant economic returns for individuals speaking the dominant language of a country or region; see for instance, the case of Hebrew in Israel (Chiswick, 1998), German in Germany (Dustmann and Van Soest, 2001), or one of the dominant languages in Canada (Chiswick and Miller, 2001) or India (Jain, 2015).
} 
Bleakley and Chin (2004) show that a person who speaks English very well earns 67\% more, and a person who speaks English well earns 33\% more compared to a person who speaks English poorly. Much of the returns is mediated through improved years of schooling among the immigrant children. Bleakley and Chin (2010) also report that English language proficiency among immigrants in the U.S. increases the probability of marrying a U.S. native, having a more educated and higher-earning spouse, and having few children. ${ }^{3}$

Given these substantial returns, why do only $4 \%$ of men in wage employment and $2 \%$ of women in wage employment in India report speaking fluently in English (Azam et al., 2013)? ${ }^{4}$ Very few studies explain why English skill acquisition remains so low. One notable exception is Shastry (2012) who argues that within India, regions with greater linguistic distance from Hindi (the dominant vernacular) were more likely to learn English. Nevertheless, the costs associated with acquiring spoken English fluency is unexplored in the literature. These include credit constraints, as students might not be able to invest in vocational training courses that yield benefits many years in the future. Additionally, distance, time and effort costs might be substantial barriers to enrolling or participating in a spoken English class or program. Finally, individuals might face soft barriers as well - for instance, a person who does not know how poor his English skills are is unlikely to enrol in a program that improves fluency.

Drawing on data from an experiment conducted among urban college students in India, this paper examines barriers that prevent acquisition of spoken English language skills. We implement a field experiment where college students in Hyderabad (India) are randomly offered vouchers that offer full, partial, or no subsidy towards the cost of a spoken English language program. We then follow up with these students after a year to understand the determinants of enrolment in the program. Exogenously varying the subsidy for the program allows us to estimate a demand function for the spoken English course that is free of selection bias. From a policy perspective, the

\footnotetext{
${ }^{3}$ Previous studies have estimated a Mincer type regression, where log earnings is regressed on spoken English skills and the OLS estimate serves as the returns to language skills (McManus et al., 1983, Kassoudji, 1988, Tanier, 1988, Chiswick, 1991).

${ }^{4}$ Approximately $16 \%$ and $6 \%$ of men and women in wage employment respectively report speaking little English (Azam et al., 2013).
} 
provision of vouchers allows analysis of the role of subsidies in improving skill accumulation in India.

A number of interesting findings emerge from our analysis. First, we find resources to be a significant barrier to take-up even among college graduates in urban Hyderabad in India. Participants who receive the full subsidy are $23 \%$ more likely to take-up the program compared to participants who receive no subsidy. We find no significant difference in take-up rates between the partial and no subsidy groups. Second, we find distance to the training center to be a significant barrier to take-up. Third, we find that pre-existing knowledge of spoken English and past enrollment in a similar course are both negatively associated with take-up. Fourth, individuals who speak Urdu at home are less likely to take-up the program. Finally, family background characteristics such as religion, gender, caste, and household size have no impact on take-up. Note that with the exception of subsidy, all other constraints to participation are not varied experimentally and therefore their impact on take-up do not have a causal interpretation. Overall, our findings indicate the need for a multipronged policy solution that integrates language proficiency courses into mainstream schooling and college education.

\section{Experimental design}

\subsection{Program description}

We examine the impact of subsidies on participating in a specific spoken English program offered by a private firm, Veta. ${ }^{5}$ Veta was established in 1981 and has national presence with over 250 centers across 140 cities in India. The spoken English course offered by Veta provides 80 hours of instruction over eight weeks. Each session lasts for two hours with regular attendance, and students are assessed at the end of the course. The program is bilingual in English and the dominant local language is used to ease communication between teachers and students. The program provides oneto-one training to account for the heterogeneity in baseline language abilities among the program

\footnotetext{
${ }^{5}$ See http://www.veta.in.
} 
participants. ${ }^{6}$

The course focuses on aspects of spoken English that are relevant in a white-collar professional environment such as interviewing and interacting with customers and colleagues. Sample topics include introducing oneself, greeting others, discussing job, business and places (including "small talk”), giving instructions, asking questions, inviting, reporting, thanking, and apologizing. The course uses classroom instruction, peer discussions, and electronic media to build vocabulary and improve phonetics (initials and finals, English phonetic alphabet, tones, neutral tone, change in intonation etc.). At the end of the course, Veta issues a certificate of completion to each participant. As noted earlier, the average returns to both fluent as well as little spoken English remains high in India, and even more for students interested in joining the service sector industry where these skills are valued and/or are critical for the job.

At the time of the study, eight Veta centers operated in Hyderabad, located in different parts of the city.

\subsection{Target population and sample selection}

The program described above was implemented in Hyderabad, a major metropolitan center in south India. Hyderabad has a large traditional sector where Urdu and Telugu are widely used. In addition, Hyderabad has a large modern sector with information technology, business process outsourcing (BPO), and biotechnology firms where English is the dominant medium of communication. Hence, a worker who learns English can potentially transition from traditional to modern sector employment.

The primary (intended) beneficiaries of this intervention are 20 to 24 year old college students in the final year of an undergraduate program. We anticipated that these students would benefit from an intervention of this kind for a number of reasons. First, students are likely to enter the formal labor market after completing their undergraduate degree. A number of students might

\footnotetext{
${ }^{6}$ This program structure is similar to that of many other commercial providers that we surveyed as part of formative research for this study.
} 
also continue education in graduate school, where the medium of instruction is almost uniformly English. Concurrently, many students might also enter the marriage market at this stage, and there could be a marriage market premium associated with spoken English skills. Second, jobs obtained after an undergraduate degree may be more directly tied to fluency in spoken English compared to blue collar jobs attained after completing high school. Since many college graduates from the city might seek employment in the modern service sector, we expect a considerable return to investing in spoken English skills. Indeed, using the Azam et al. (2013) methodology with the India Human Development Survey (2005) data, we estimate that in Hyderabad, speaking fluent English is associated with $44.2 \%$ higher earnings and speaking a little English is associated with $36.2 \%$ higher earnings, both compared to not speaking any English, numbers that are higher than the national average. ${ }^{7}$

We started with a list of all colleges affiliated to Osmania University and Jawaharlal Nehru Technological University, the two main undergraduate universities located in Hyderabad. From this list, we randomly selected a set of 16 colleges to target. In the last quarter of 2011 , we conducted a complete census of third year students enrolled in these colleges. ${ }^{8}$ The census collected information on individual's age, gender, permanent residence, self-reported measure of spoken English, and perceptions about benefits from improving spoken English skills. Based on this census, we excluded all students who resided in a hostel (since temporary migrants to the city are more difficult to track in a panel survey) and students who rated their ability to speak in English as "very fluent" (since these students were unlikely to take-up an English course). We then stratified our sample on the basis of gender. This stratification is important as there exists substantial differences in job opportunities available to men and women in the service sector which are likely to result in heterogeneity in both take-up rates and subsequent returns (Jensen, 2010, Oster and Steinberg, 2013).

Column 1 of Table 1 presents the summary statistics from the census survey. A little over half

\footnotetext{
${ }^{7}$ The results are available upon request.

${ }^{8}$ An enumerator conducted the census at each college on a single day. Students who were absent from college on that day are not part of our census. Hence, chronically absent students are disproportionately missing from the census.
} 
the respondents $(51.3 \%)$ reported that they spoke English fluently. Of the remaining, $45.4 \%$ answered that they knew a "little English", which is consistent with many students without English medium education enrolling in a university where they are taught primarily in English. Nonetheless, more than $90 \%$ of the respondents expressed a desire to improve their spoken English skills, citing improved job prospects (12.2\%), communications skills (35.2\%), confidence (49.0\%), and marriage market outcomes $(1.1 \%)$ as motivations for doing so. A majority $(56.5 \%)$ reported that they planned to enroll in a spoken English language program to improve their skills, although few knew about the cost of such a program.

We contacted a random sample of 755 college students to participate in a longer survey. Each individual who agreed to participate in the baseline survey was randomly assigned to receive a voucher of one of the following amounts: Rs. 2,000 (Gold), Rs. 1,000 (Silver), and Rs. 0 (Bronze). Of these 755 students targeted, 444 (approximately 60\%) completed the baseline survey. A comparison of observable characteristics between participants and non-participants in the baseline survey reported in Table 1 shows that individuals that participated in the survey are not systematically different from those who chose not to participate in the survey (see Column 4 of Table 1). The vouchers were purposely disseminated only at the end of the survey to rule-out differential survey responses by subsidy amount.

Our treatment entails randomly allocating vouchers in varying amounts that subsidizes the cost of obtaining the spoken English language course to our target sample in the study. The full retail price of the program is Rs. 2,000. Students were randomly allocated vouchers that covered $100 \%$ (Rs. 2,000 ), $50 \%$ (Rs. 1,000) or $0 \%$ (Rs. 0) of the program price, which also represents the different treatments. Students could enrol in any Veta center in Hyderabad.

The provision of vouchers of different amounts plays several important roles. First, analysis of the take-up rate based on random assignment to the different treatment groups (defined by the three different subsidy amounts) allows us to estimate a demand function for spoken English course that is free of selection bias. Second, the provision of vouchers allows us to inform policy makers about the role of subsidies in improving skill accumulation in India. Finally, variation in take-up 
by voucher amount can inform policy makers about the magnitude of the subsidy that is required to target effectively.

To minimize risks from possible contamination bias, vouchers were designed to be tamper proof, non-transferable and expire within 12 weeks of issue. During the baseline survey, enumerators took pictures of the respondents. These pictures along with the voucher's unique id and amount were given to Veta to ensure that the vouchers are used only by the study participants to whom they were assigned and not traded to anyone else. See Figure 1 for a sample voucher.

\section{Data}

The baseline survey was conducted from December 2011 to March 2012, and collected data on household demographic characteristics (age, gender, education, etc. of all members in the household), household assets, educational loans, and detailed individual level information on labor market outcomes (casual wage employment, permanent wage employment, self-employment, earnings, job interview performance, job search, duration of employment, hours worked), life satisfaction measures (happiness at work, happiness at home), preference parameters (present biased, expected returns from English language skill accumulation measured using Likert scales), bargaining power (questions on household decision making, participation in rotating savings and credit associations), mode of transportation to college, distance to college (and training centers), and measures on the quality of English language skill already accumulated.

\subsection{Measuring spoken English skills}

The baseline survey asks participants for subjective (self-reported and self-assessed) measures of spoken English skills by ranking their ability to speak fluently in English on a scale of 1 to 5 (Excellent to cannot speak English), which are re-coded to a scale of 1 to 3 (1: good; 2: average; 3: poor). However, this subjective measure is likely to suffer from systematic measurement error bias. To mitigate this problem, we devise an additional measure of spoken English skills that is 
less susceptible to systematic measurement error. Enumerators asked respondents to translate a passage from their mother tongue (Telugu, Urdu, or Hindi) into English. Two independent graders assessed each voice recording. These were again coded on a scale of 1 to 5 (From "excellent" to “cannot speak English") and re-coded on a 3-point scale (1: good; 2: average; 3: poor). ${ }^{9}$

Our survey design therefore enables us to obtain a better understanding of the deviation between an individual's self-reported ability to speak in English and their objectively measured ability to speak in English (see Figure 2). On average, individuals have an inflated view of their spoken English skills. Less than $6 \%$ of individuals report having poor or no spoken English skills, whereas almost $40 \%$ are identified as having poor or no spoken English skills using the objective measure. While 55\% of the participants self-report having good spoken English skills, the objective measure reports that only $20 \%$ actually have good spoken English skills. There is little discrepancy among those who think their spoken English skills are average - about 39\% of the sample reports having average skills and the same proportion is also identified as having average skills using the objective measures. About $27 \%$ of individuals are correctly able to evaluate their spoken English ability (i.e., their self-reported and actual abilities match). Figure 3 summarizes these findings, with the size of the plots being representative of the frequency associated with that combination of objective and subjective measures of spoken English skills.

In sum, $61 \%$ of the participants have an inflated view of their ability to speak in English. Even in the presence of full information on the returns to spoken English skills, this asymmetric information in knowledge about spoken English ability can result in low take-up rates. We investigate this issue further in the results section.

We conducted a follow up telephone survey in May 2013. We were successful in contacting 387 of the original 444 participants. This survey collected data on academic outcomes, participation in skill-development programs (at Veta or elsewhere), reasons for non-participation, employment outcomes (job characteristics, industry, wages, benefits etc.) and possible marital outcomes. Data from this survey helped to investigate reasons for low program take-up.

\footnotetext{
${ }^{9}$ The final grade allocated to each participant was the average of the grades assigned by the two independent graders.
} 


\subsection{Randomization and sample balance}

An implication of our experimental design is that none of the baseline characteristics must be significantly different across the treatment arms (Gold, Silver, and Bronze). Table 2 presents the baseline mean and standard deviation of all key variables used in the analysis, separated by treatment arms: Gold, Silver, and Bronze. Column 4 presents $p$-values from an ordered probit regression model, where the dependent variable, subsidy ( $=2$ if full subsidy, $=1$ if partial subsidy, $=0$ if no subsidy) is individually regressed on each of the covariates, showing that the baseline characteristics are not different across the three treatment arms, except for performance on the objective measure of spoken English (in average) and distance from college to the nearest Veta center. The overall joint $F$-test on the regression of the subsidy on all baseline covariates in an ordered probit specification shows that we cannot reject the null hypothesis that the baseline characteristics jointly do not predict assignment into the treatment arms $(p-$ value $=0.71)$.

\section{Empirical analysis}

The overall take-up rate defined as the proportion of students who join the Veta course is 12 percent. However, Figure 4 shows that the take-up rate varies considerably by treatment arms: only $1.3 \%$ in the group that receives no subsidy (Bronze), $5.4 \%$ in the group that receives partial subsidy (Silver), and $18.1 \%$ in the group that receives the full subsidy. But given substantial returns to spoken English in India and abroad, why is enrollment in the course so low? The rest of this section focusses on identifying the role of subsidies and other factors in influencing program participation.

\subsection{Specification}

To determine the factors that affect enrollment in Veta's program, we estimate the following regression.

$$
\text { Take_up } i=\alpha_{0}+\alpha_{1} \text { Gold }_{i}+\alpha_{2} \text { Silver }_{i}+\sum_{j=1}^{K} \gamma_{j} \mathbf{Z}_{i j}+\epsilon_{i}
$$


where the dependent variable, Take_up $p_{i}$ is a binary variable that is 1 if the individual enrols in the spoken English language course offered by Veta, and 0 otherwise. We examine the impact of following observable factors on program enrollment: (i) subsidies (Gold and Silver), (ii) distance to training center, (iii) knowledge of spoken English skills, (iv) mother tongue influence, and (v) family background characteristics. We sequentially estimate a number of different specifications. Specification (1) in Table 3 captures the influence of subsidies using the two treatment dummies, Gold and Silver, which are 1 if the individual was randomly allocated a gold or silver voucher respectively, and 0 otherwise. The reference category is the individual with the bronze voucher. Specification (2) includes a vector of family background characteristics (age, gender, caste, religion, household size, and degree enrolled) that are included in all the following specifications. Specification (3) controls for access to Veta center using: distance from the college the participant is enrolled in to the nearest Veta center and distance from the participant's home to the nearest Veta center. ${ }^{10}$ The distance measure captures additional costs of attending the program such as time costs as well as transportation costs. Specification (4) includes objective (dummies for good and average ability, poor ability is the reference category) and subjective (dummies for good and average ability, poor ability is the reference category) measures of spoken English ability (as discussed in Section 3.1). The specification also controls for past enrollment in a spoken English course. Finally, the last specification in Column 5 controls for mother tongue influence, i.e., the role of the dominant language spoken at home on learning spoken English skills.

\subsection{Results}

Table 3 presents the regression results as marginal effects from a probit regression with robust standard errors in parentheses. Participants who receive the full Gold subsidy are $23 \%$ more likely to enroll in the program $(p<0.01)$ compared to individuals who receive no subsidy. Receiving the partial Silver subsidy increases the probability of enrolling in the program by almost 10 percent-

\footnotetext{
${ }^{10}$ This distance is computed using Google Maps and does not take into account time-varying traffic conditions or other factors that effect actual transportation costs.
} 
age points (compared to no subsidy), although the effect is not statistically significant. The effect of full Gold subsidy is significantly different from the effect of the partial subsidy (the null hypothesis, Gold $=$ Silver is consistently rejected at the $1 \%$ level.). This suggests both that resource constraints act as a significant barrier to English language training, and that full cost subsidies are required to generate significant take-up. These findings are consistent with previous experimental research conducted in developing countries that shows both that demand for a number of high return investments in health and education are sensitive to prices, ${ }^{11}$ and that the relationship between product price and adoption is negative.

Column 3 in Table 3 finds that local access is a significant driver of program participation. Every additional kilometer from the college to the training center decreases the probability of enrolling in the program by 0.7 percentage points $(p<0.05)$. This result is corroborated by the non-parametric lowess plot (see Figure 5) of the distance from college to the nearest Veta center. To put this finding in perspective, note that an auto-rickshaw, a popular mode of travel among youth, costs Rs. 9 per kilometer in Hyderabad. The influence of distance to school or training center is echoed by other studies as well. For example, Muralidharan and Prakash (2016) report that distance to school is a major factor in secondary school enrollment in Bihar, but the provision of bicycles helps mitigate transportation costs. Similarly, Burde and Linden (2013) investigate the role of placing a primary school in a village, and find dramatic increases in school enrollment and attendance, especially for girls. In the context of Indonesia, Duflo (2001) found both schooling and labor market participation positively impacted when new school construction reduced the distance to the closest school. ${ }^{12}$ In our context, these findings are not surprising, since students reported often attending classes after college ends for the day. Therefore, one policy implication of this

\footnotetext{
${ }^{11}$ See, for example, research on the relationship between price and adoption studied in the context of bed-nets for malaria prevention (Cohen and Dupas, 2010), deworming pills for stomach infections (Kremer and Miguel, 2004), water disinfectants (Ashraf et al., 2010), merit scholarships (Kremer et al., 2009) and learning HIV status (Thornton, 2008).

${ }^{12}$ The negative relationship between distance and program take-up is well founded in the literature. Thornton (2008) finds a negative relationship between distance to voluntary counseling and testing center and learning HIV status in Malawi, Devoto et al. (2012) report that distance to the closest public tap is positively related to adopting a piped water connection in Morocco, and Suri (2011) records that the distance to fertilizer provider is negatively related to fertilizer adoption even among farmers who had the highest returns from using the fertilizer.
} 
result is that skill training centers should be located near colleges to reduce transportation and time costs associated with attendance.

The program is unlikely to benefit individuals with relatively better spoken English skills. Consistent with this hypothesis, Column 4 in Table 3 finds that participants with good spoken English skills are almost 6 percentage points less likely to enroll in the program $(p<0.01)$. This result is qualitatively consistent in Column 5 when additional factors that might impact program participation are added to the specification. Similarly, Columns 4 and 5 report that prior enrollment in a spoken English course reduces program participation by $3.3(p>0.10)$ and $3.7(p<0.10)$ percentage points, respectively. This suggests that policy makers interested in efficient targeting of language or skill training subsidies should incorporate screens to exclude participants with preexisting high quality skills or prior experience in training programs.

Finally, the last specification also controls for mother tongue/dominant language spoken at home. Column 5 reports a 5 percentage point decline in program take-up rates if Urdu is the mother tongue $(p<0.05)$. While most Urdu speakers in Hyderabad are Muslims, this result most probably captures linguistic or cultural factors rather than religious ones since the specification controls for the participant's religion. Finally, Table 3 does not show significant influence of socioeconomic and demographic characteristics on program adoption, a result that is consistent across different specifications. ${ }^{13}$

The follow-up interview conducted one year after the distribution of vouchers sought to understand the reasons behind low program participation. Individuals who did not enroll were asked why they did so, with Panel A in Figure 6 summarizing the reasons for non-participation. Almost $48 \%$ reported that they were interested in improving their English skills, but could not enroll in the program due to time and distance constraints. Another $20 \%$ were either interested but could not commit because of personal reasons or provided some other reason for not being interested.

\footnotetext{
${ }^{13}$ Additional specifications explore the impact of the expected returns to learning spoken English. We include measures on perceptions on whether spoken English skills have a large impact on labor and marriage market outcomes. None of these additional variables have a statistically significant effect on take-up rate and the inclusion of these variables does not change the magnitude of the main coefficients of interest. These are not shown in this paper, but available upon request from the authors.
} 
Approximately $32 \%$ of those who did not use the offer cited no interest in either improving their skills or the program as the main reason for non-participation.

In Panel B of Figure 6 presents reasons for non-participation by voucher type. Larger subsidies increase the likelihood that participants report distance and time commitments as more important barriers to adoption, and decreases the likelihood of "not interested". What is notable is that distance continues to be a significant barrier to program take-up that cannot be closed through subsidizing the cost of the program.

Our findings should be placed in the context of other studies that have also found significant barriers to take-up, completion, and effectiveness of skill development programs. Field et al. (2010) report that traditional religious and caste institutions in India restrict women's ability to participate in a business training program in rural India. In contrast, Dasgupta et al. (2015) find that behavioural factors such as preferences for risk and competition influence the decision to apply for a vocational training program in urban India. Maitra and Mani (2015) find that distance to the training centre and lack of childcare facilities are significant barriers to women completing and thereby maximizing value of a subsidized training program. Jensen (2010) finds that in the Dominican Republic, lack of information about returns to education have significant impact on boys' continuation to secondary school.

We also estimate the returns to program participation. While the returns are positive, the power resulting from low program participation prevents us from drawing definite conclusions.

\section{Discussion}

Despite potentially high returns to English language fluency documented by popular and scientific literature, few students and workers invest in spoken English fluency. This paper illustrates that a range of constraints bind when considering why enrollment in spoken English courses is so low. Using a randomized field experiment that subsidized the cost of learning spoken English among college students in Hyderabad, we show that students are price sensitive and only a full subsidy 
has a positive and significant impact on program enrollment. Our results also show that distance, ability, and experience - all significantly affect the likelihood of enrolling in the program. Thus, consistent with the larger literature on the factors that influence participation in vocational training programs, we find that subsidies as well as removing a large number of other constraints, especially distance and time costs, are important elements in increasing program enrollment.

These results should be read with a number of caveats. First, just because we identify a set of barriers to English language acquisition in this situation does not imply that our findings will readily generalize to all settings. For example, we assumed given the context of urban Hyderabad the availability of service sector jobs with labor market returns to English skills. However, in the context of areas with fewer opportunities for service sector employment, the potentially lower returns to spoken English might be an important barrier to investment in skill acquisition. Our results are also perhaps specific to a certain program offered by Veta, and the take-up rates might be significantly different for a program that teaches different material, or teaches in a different way.

A related issue is that our experiment was conducted with a specific population of final year undergraduate students. This group might be particularly time constrained, for instance with job search, and so experience relatively higher costs of attendance in the program. An experiment with college students might also be cognitively too late, since prior research has shown greater facility to learn new languages early in life (Johnson and Newport, 1989, Flege et al., 1999). Future research could examine English language training earlier in life, for example through school-based programs that target younger populations and where the program is integrated into the curriculum to facilitate attendance.

Finally, we do not explore the effects of peers and the broader social environment in acquiring spoken English skills, which are potentially important since learning new languages is an inherently social activity. Prior literature shows the importance of peer ability on academic learning (Jain and Kapoor, 2015) as well as a range of other outcomes (Dasgupta et al., 2015) in college. Similarly, neighborhood effects are also potentially influential in language acquisition. Future research could illustrate the degree of these peer and neighborhood effects in English language 
acquisition. Given significant inconsistencies in self-perception of ability and actual ability uncovered by this paper, future research could examine the role of social factors in perception formation, especially related to language ability. If these social influences are large, then group subsidies to learn English might be more effective than individually targeted ones.

Nonetheless, this paper emphasizes the importance of a multi-dimensional approach to removing barriers to skill acquisition, an important lesson for policy-makers investing in skill acquisition across the developing world. 


\section{References}

Ashraf, N., J. Berry, and J. Shapiro (2010). Can higher prices stimulate product use? Evidence from a field experiment in Zambia. American Economic Review 100(5), 2383-2413.

Azam, M., A. Chin, and N. Prakash (2013). The returns to English-language skills in India. Economic Development and Cultural Change 2(61), 335-367.

Bleakley, H. and A. Chin (2004). Language skills and earnings: Evidence from childhood immigrants. Review of Economics and Statistics 86(2), 267-298.

Bleakley, H. and A. Chin (2010). Age at arrival, English proficiency, and social assimilation among US immigrants. American Economic Journal: Applied Economics 2(1), 165-92.

Burde, D. and L. Linden (2013). Bringing education to Afghan girls: A randomized controlled trial of village-based schools. American Economic Journal: Applied Economics 5(3), 27-40.

Card, D., J. Kluve, and A. Weber (2010). Active labour market policy evaluations: A metaanalysis. Economic Journal 120(548), F452-F477.

Chakraborty, T. and S. Kapur (2016). English language premium: Evidence from a policy experiment in India. Economics of Education Review 50, 1 - 16.

Chamarbagwala, R. and G. Sharma (2011). Industrial de-licensing, trade liberalization, and skill upgrading in India. Journal of Development Economics 96(2), 314-336.

Chiswick, B. (1991). Speaking, reading, and earnings among low-skilled immigrants. Journal of Labor Economics 9(1), 149-170.

Chiswick, B. (1998). Hebrew language usage: Determinants and effects on earnings among immigrants in Israel. Journal of Population Economics 11(2), 253-271.

Chiswick, B. and P. Miller (2001). A model of destination-language acquisition: Application to male immigrants in Canada. Demography 38(3), 391-409.

Cohen, J. and P. Dupas (2010). Free distribution or cost-sharing? Evidence from a randomized malaria prevention experiment. Quarterly Journal of Economics 125(1), 1-45.

Dasgupta, U., L. Gangadharan, P. Maitra, S. Mani, and S. Subramanian (2015). Choosing to be trained: Evidence from a field experiment. Journal of Economic Behavior and Organization 110, $145-159$. 
Dasgupta, U., S. Mani, S. Sharma, and S. Singhal (2015). Cognitive and non-cognitive returns to college quality: Evidence from India. Fordham University Working Paper.

Devoto, F., E. Duflo, P. Dupas, W. Parienté, and V. Pons (2012). Happiness on tap: Piped water adoption in urban Morocco. American Economic Journal: Economic Policy 4(4), 68-99.

Duflo, E. (2001). Schooling and labor market consequences of school construction in Indonesia: Evidence from an unusual policy experiment. American Economic Review 91(4), 795-813.

Dustmann, C. and A. Van Soest (2001). Language fluency and earnings: Estimation with misclassified language indicators. Review of Economics and Statistics 83(4), 663-674.

Field, E., S. Jayachandran, and R. Pande (2010). Do traditional institutions constrain female entrepreneurship? A field experiment on business training in India. American Economic Review 100(2), 125-9.

Flege, J., G. Yeni-Komshian, and S. Liu (1999). Age constraints on second-language acquisition. Journal of Memory and Language 41(1), 78 - 104.

Jain, T. (2015). Common tongue: The impact of language on educational outcomes. Indian School of Business Working Paper ISB-WP/103/2011.

Jain, T. and M. Kapoor (2015). The impact of study groups and roommates on academic performance. Review of Economics and Statistics 97(1), 44-54.

Jain, T. and P. Sarda (2014). Job markets that work: Challenges of match-making in an emerging economy. Mimeo, Indian School of Business.

Jensen, R. (2010). The (perceived) returns to education and the demand for schooling. Quarterly Journal of Economics 125(2), 515-548.

Johnson, J. and E. Newport (1989). Critical period effects in second language learning: The influence of maturational state on the acquisition of English as a second language. Cognitive Psychology 21(1), 60 - 99.

Kassoudji, S. (1988). English language abilities and the labor market opportunities of Hispanic and east Asian men. Journal of Labor Economics 6(2), 205-28.

Kremer, M. and E. Miguel (2004). Worms: Identifying impacts on education and health in the presence of treatment externalities. Econometrica 72(1), 159-217.

Kremer, M., E. Miguel, and R. Thornton (2009). Incentives to learn. Review of Economics and Statistics 91(3), 437-456. 
Lang, K. and E. Siniver (2009). The return to English in a non-English speaking country: Russian immigrants and native Israelis in Israel. The BE Journal of Economic Analysis $\mathcal{E}$ Policy 9(1).

Levinsohn, J. (2007). Globalization and the returns to speaking English in South Africa. In Globalization and Poverty, pp. 629-646. Chicago IL: University of Chicago Press.

Maitra, P. and S. Mani (2015). Learning and earning: Evidence from a randomized evaluation in India. Fordham University Working Paper No. dp2013-02.

Mankiw, G. and P. Swagel (2006). The politics and economics of offshore outsourcing. Journal of Monetary Economics 53(5), 1027 -1056.

McManus, W., W. Gould, and F. Welch (1983). Earnings of Hispanic men: The role of English language proficiency. Journal of Labor Economics 1(2), 101-130.

Ministry of Skill Development and Entrepreneurship (2015). National Policy for Skill Development and Enterpreneurship. Technical report, New Delhi.

Munshi, K. and M. Rosenzweig (2006). Traditional institutions meet the modern world: Caste, gender and schooling choice in a globalizing economy. American Economic Review 96(4), $1225-1252$.

Muralidharan, K. and N. Prakash (2016). Cycling to school: Increasing secondary school enrollment for girls in India. American Economic Journal: Applied Economics forthcoming.

Oster, E. and B. Steinberg (2013). Do IT service centers promote school enrollment? Evidence from India. Journal of Development Economics 104, 123-135.

Shastry, K. (2012). Human capital response to globalization: Education and information technology in India. Journal of Human Resources 47(2), 287-330.

Subramanian, T. S. R. (2016). Report of the Committee for Evolution of the New Education Policy. Government of India, New Delhi.

Suri, T. (2011). Selection and comparative advantage in technology adoption. Econometrica 79(1), 159-209.

Tanier, E. (1988). English language proficiency and the determination of earning among foreignborn men. Journal of Human Resources 23, 108-102.

Thornton, R. (2008). The demand for, and impact of, learning HIV status. American Economic Review 98(5), 1829-1863. 
World Bank (2008). Skill development in India: The vocational education and training system. Technical report. Report No. 22. 


\section{Appendix : Test of Proficiency in Spoken English}

((Instructions: This text is in Urdu/Telegu. You have to tanslate and read it aloud in English. You will be given five minutes. After that, you will face the voice recorder and read the given text in English)

State Bank of India is looking for a bank Manager to head its Ameerpet branch. Seeking individuals with 5 years+ work experience. Working hours will be 8:30 AM to 6 PM. Excellent benefits including attractive retirement plan. Contact abc@yahoo.com for more information. 
Figure 1: Voucher

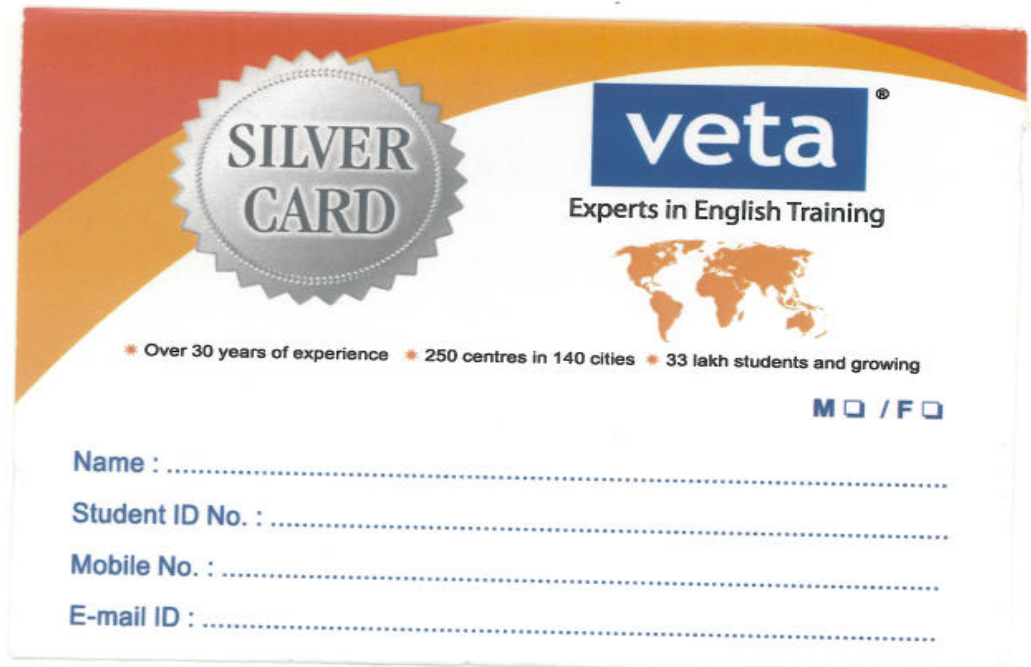

\section{Value of this Silver Card ₹ 1000}

Course entitled: Fluent English 80 hours

Batch commencement date :

Batch Hours : From .............................

To

Valid At The veta Centre Located at:

*Ameerpet 32425451 *Narayanaguda 032402661

*Dilsukh Nagar @ 32599533 * Secunderabad @ 32402660

*SR Nagar

32424526

* Santhosh Nagar (I S Sadan) 332577226

recapply

- Offer cannot be clubbed witb any otber prevalent affers. 
Figure 2: Objective versus Subjective Measures of Fluency in Spoken English

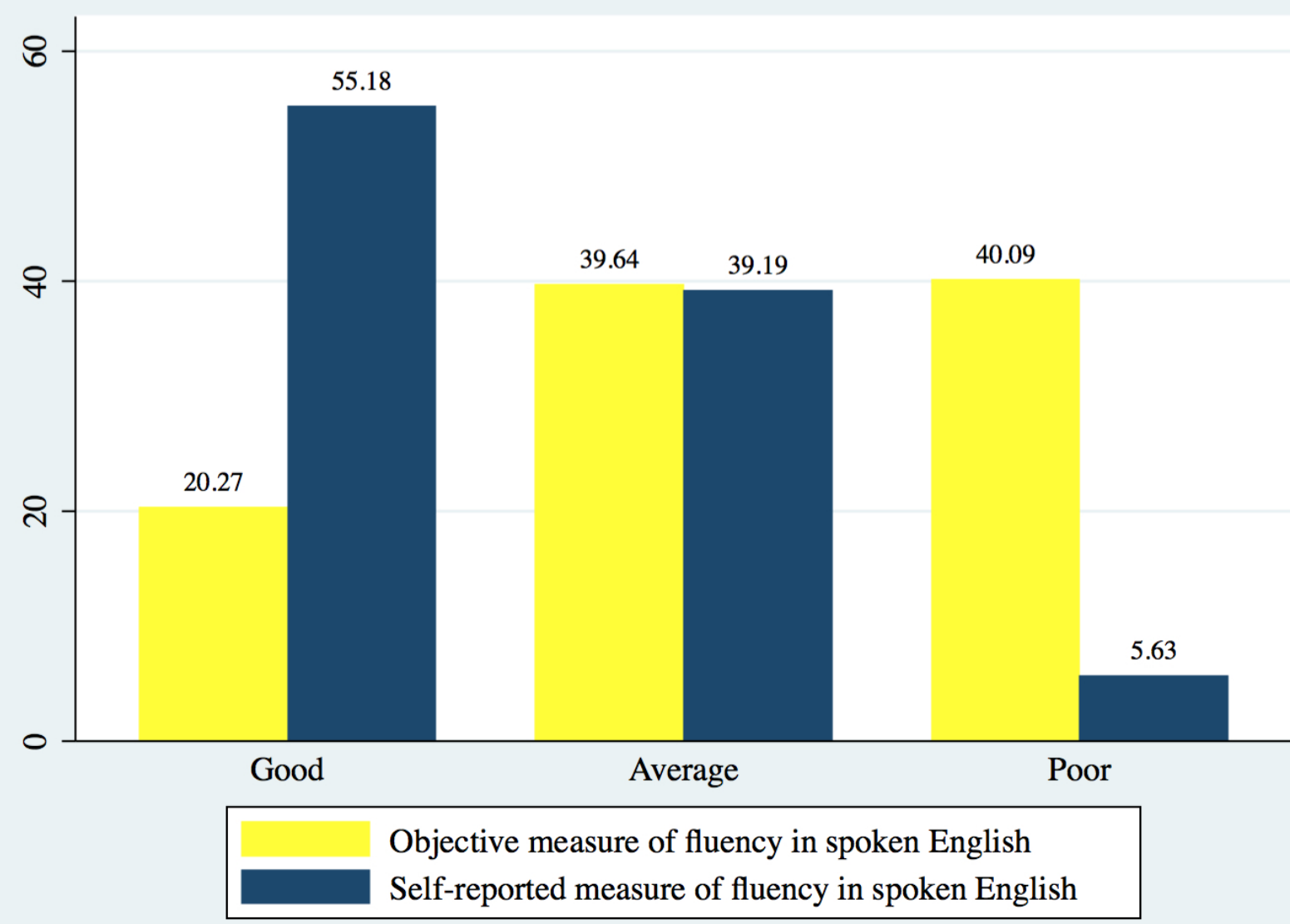


Figure 3: Under and Over estimation of Fluency in Spoken English

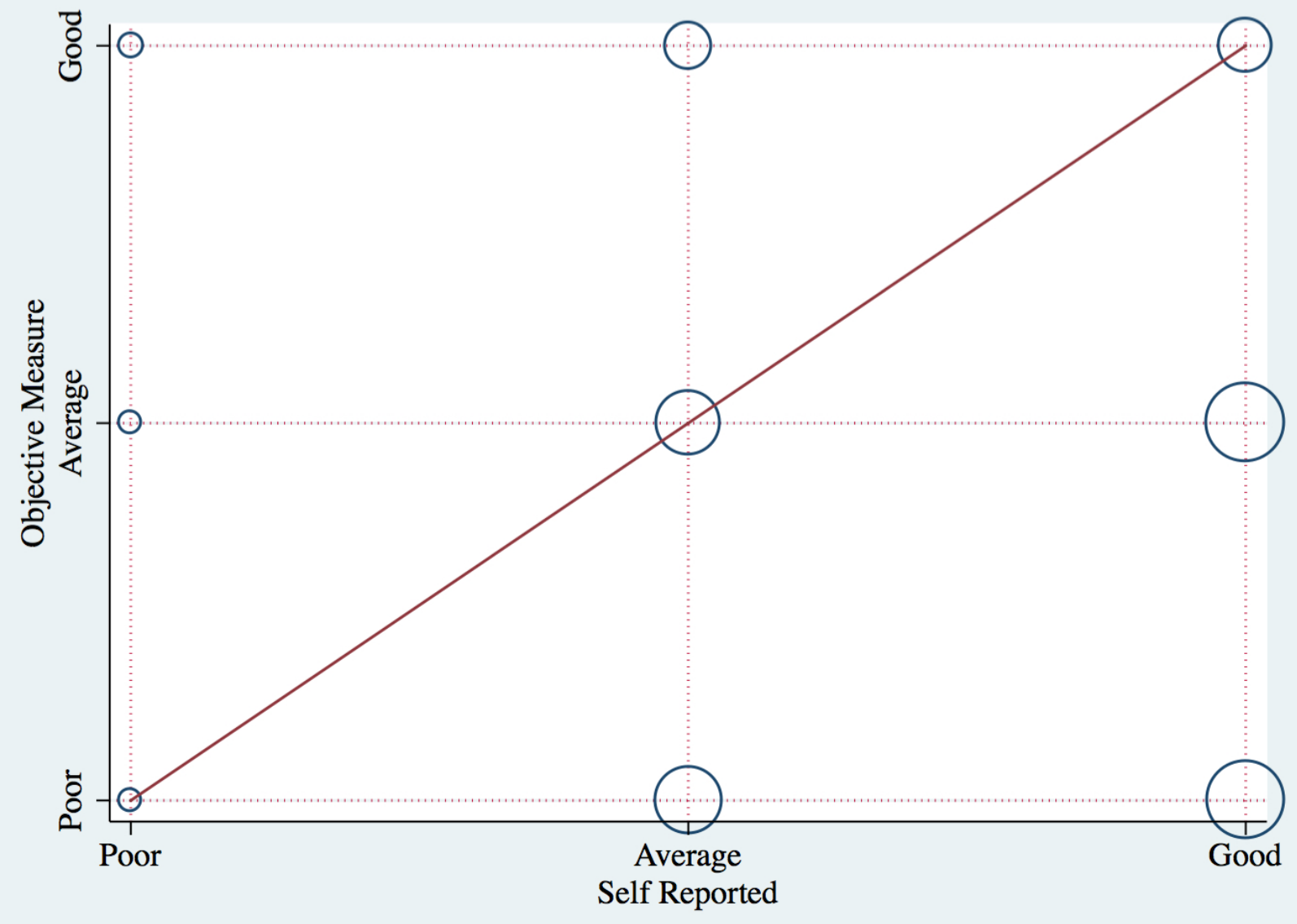


Figure 4: Take-up rate by subsidy groups

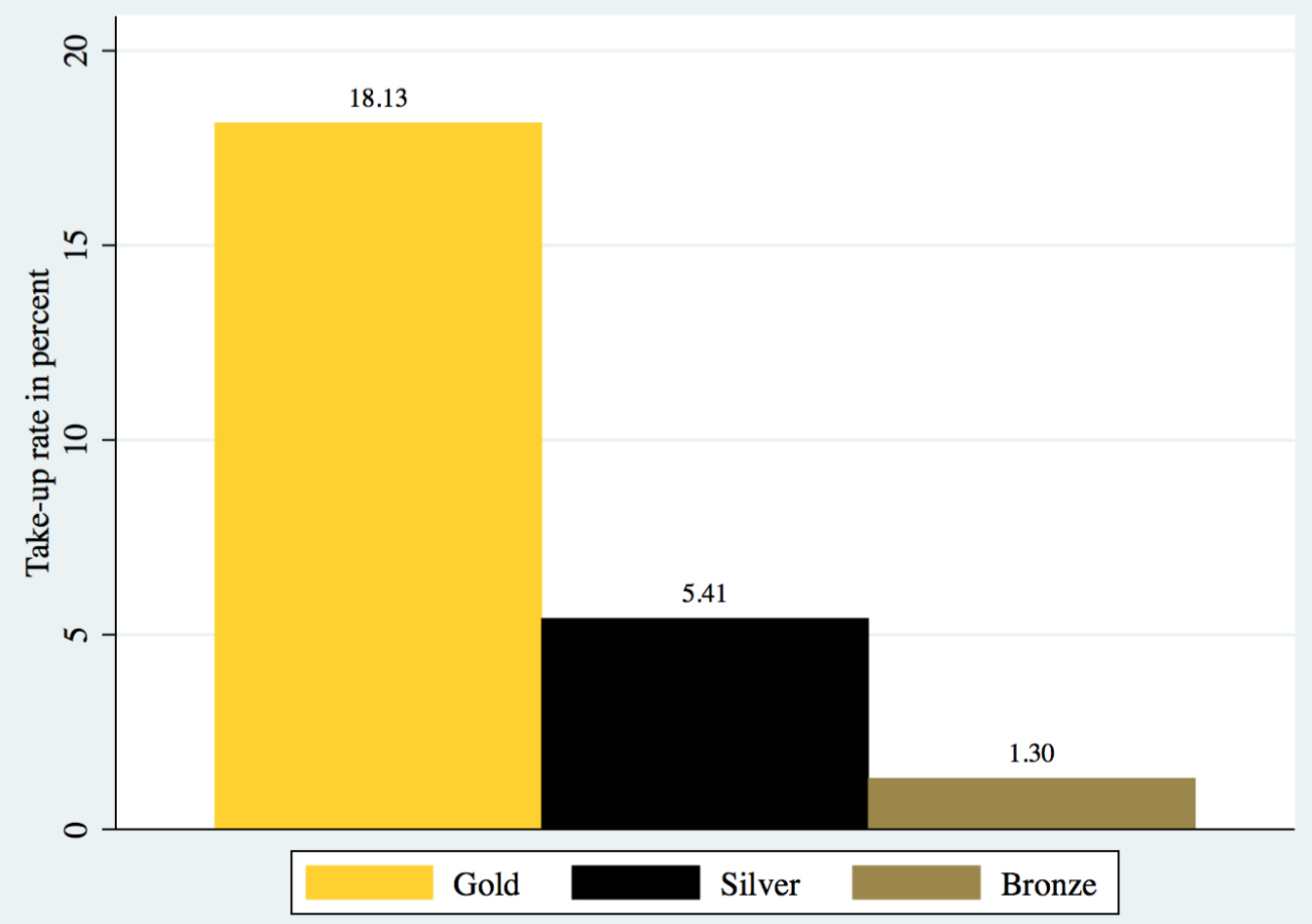


Figure 5: Distance to nearest center and take-up

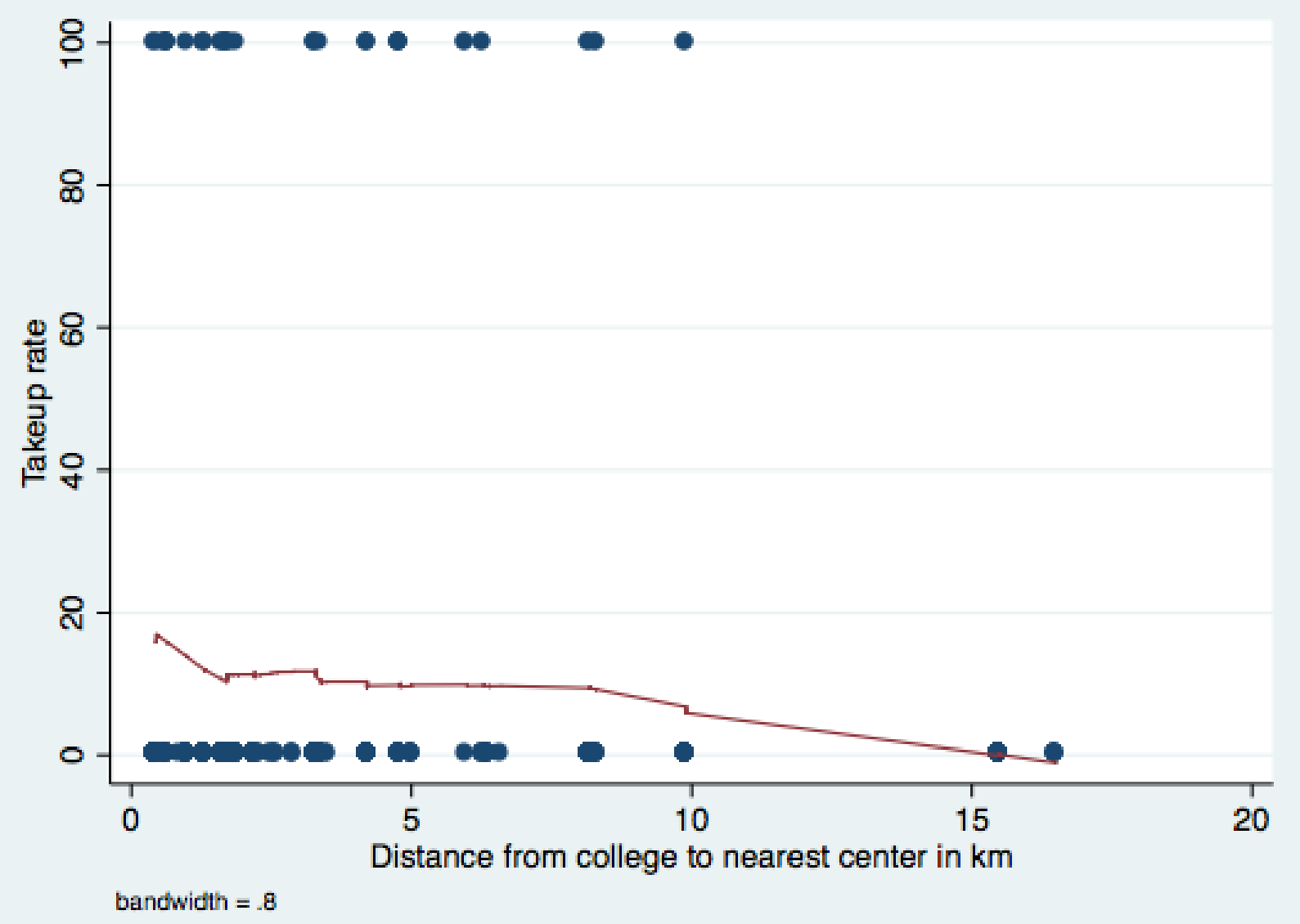




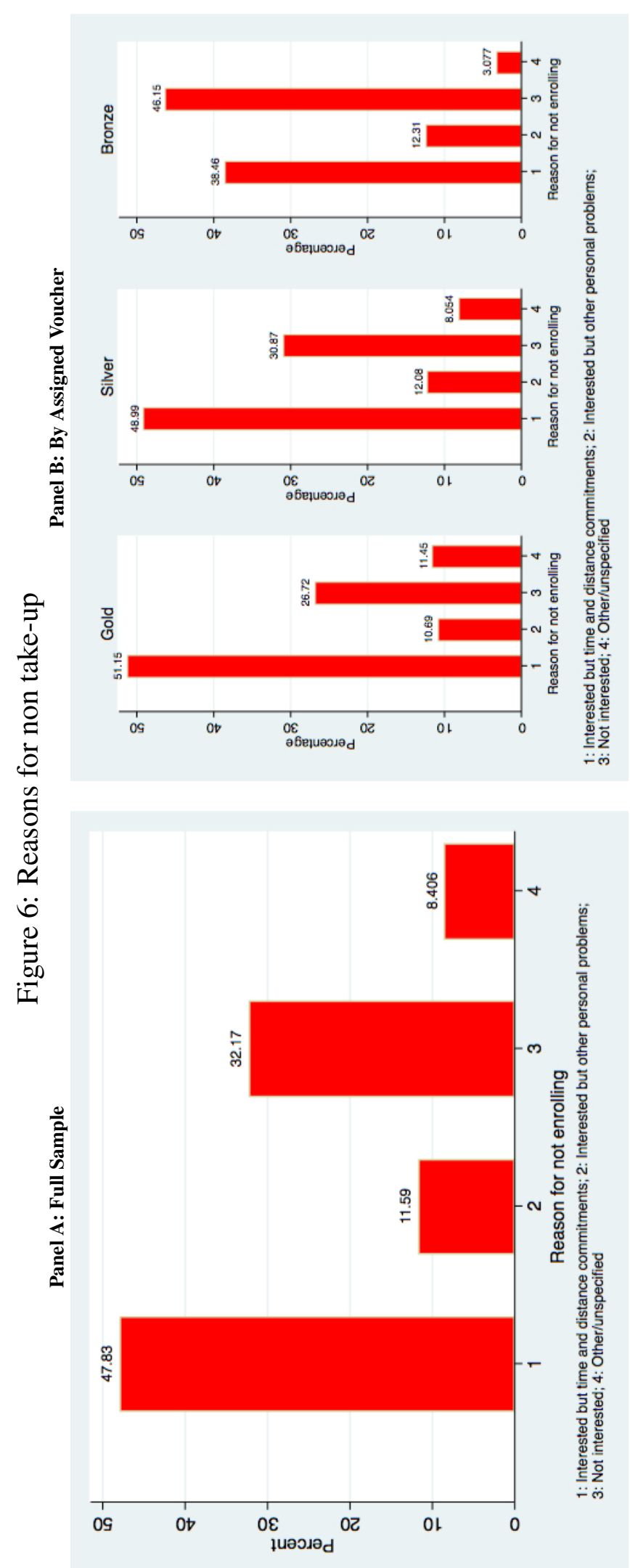


Table 1: Survey Participants and Non-Participants

\begin{tabular}{|c|c|c|c|c|}
\hline & $\begin{array}{c}\text { Full Sample } \\
\text { (1) }\end{array}$ & $\begin{array}{c}\text { Mean } \\
\text { Not Surveyed } \\
\text { (2) }\end{array}$ & $\begin{array}{c}\text { Surveyed } \\
\text { (3) }\end{array}$ & $\begin{array}{c}\text { Difference } \\
\text { t-test } \\
(4)\end{array}$ \\
\hline Fluent English & $\begin{array}{c}0.513 \\
(0.500)\end{array}$ & $\begin{array}{c}0.540 \\
(0.499)\end{array}$ & $\begin{array}{c}0.493 \\
(0.501)\end{array}$ & $\begin{array}{c}0.047 \\
(0.037)\end{array}$ \\
\hline Little English & $\begin{array}{c}0.454 \\
(0.498)\end{array}$ & $\begin{array}{c}0.434 \\
(0.496)\end{array}$ & $\begin{array}{c}0.468 \\
(0.500)\end{array}$ & $\begin{array}{l}-0.034 \\
(0.037)\end{array}$ \\
\hline No English & $\begin{array}{c}0.033 \\
(0.179)\end{array}$ & $\begin{array}{c}0.026 \\
(0.159)\end{array}$ & $\begin{array}{c}0.038 \\
(0.192)\end{array}$ & $\begin{array}{l}-0.012 \\
(0.013)\end{array}$ \\
\hline Want to learn how to speak English better & $\begin{array}{c}0.903 \\
(0.296)\end{array}$ & $\begin{array}{c}0.920 \\
(0.272)\end{array}$ & $\begin{array}{c}0.892 \\
(0.311)\end{array}$ & $\begin{array}{c}0.028 \\
(0.022)\end{array}$ \\
\hline Value of able to speak English better: Jobs & $\begin{array}{c}0.122 \\
(0.327)\end{array}$ & $\begin{array}{c}0.113 \\
(0.317)\end{array}$ & $\begin{array}{c}0.128 \\
(0.335)\end{array}$ & $\begin{array}{l}-0.016 \\
(0.024)\end{array}$ \\
\hline Value of able to speak English better: Communicate & $\begin{array}{c}0.352 \\
(0.478)\end{array}$ & $\begin{array}{c}0.341 \\
(0.475)\end{array}$ & $\begin{array}{c}0.360 \\
(0.481)\end{array}$ & $\begin{array}{l}-0.020 \\
(0.035)\end{array}$ \\
\hline Value of able to speak English better: Confidence & $\begin{array}{c}0.490 \\
(0.500)\end{array}$ & $\begin{array}{c}0.527 \\
(0.500)\end{array}$ & $\begin{array}{c}0.464 \\
(0.499)\end{array}$ & $\begin{array}{c}0.063 \\
(0.037)\end{array}$ \\
\hline Value of able to speak English better: Marriage & $\begin{array}{c}0.011 \\
(0.102)\end{array}$ & $\begin{array}{c}0.009 \\
(0.098)\end{array}$ & $\begin{array}{c}0.011 \\
(0.106)\end{array}$ & $\begin{array}{l}-0.002 \\
(0.007)\end{array}$ \\
\hline Planning to enrol in an English language course & $\begin{array}{c}0.566 \\
(0.496)\end{array}$ & $\begin{array}{c}0.572 \\
(0.496)\end{array}$ & $\begin{array}{c}0.561 \\
(0.497)\end{array}$ & $\begin{array}{c}0.011 \\
(0.037)\end{array}$ \\
\hline Know cost of such a course & $\begin{array}{c}0.135 \\
(0.342)\end{array}$ & $\begin{array}{c}0.154 \\
(0.362)\end{array}$ & $\begin{array}{c}0.121 \\
(0.327)\end{array}$ & $\begin{array}{c}0.033 \\
(0.025)\end{array}$ \\
\hline Degree B.Sc & $\begin{array}{c}0.287 \\
(0.453)\end{array}$ & $\begin{array}{c}0.280 \\
(0.450)\end{array}$ & $\begin{array}{c}0.293 \\
(0.456)\end{array}$ & $\begin{array}{l}-0.013 \\
(0.033)\end{array}$ \\
\hline Degree B.Com & $\begin{array}{c}0.509 \\
(0.500)\end{array}$ & $\begin{array}{c}0.511 \\
(0.501)\end{array}$ & $\begin{array}{c}0.507 \\
(0.501)\end{array}$ & $\begin{array}{c}0.004 \\
(0.037)\end{array}$ \\
\hline Degree Other & $\begin{array}{c}0.192 \\
(0.394)\end{array}$ & $\begin{array}{c}0.206 \\
(0.405)\end{array}$ & $\begin{array}{c}0.182 \\
(0.387)\end{array}$ & $\begin{array}{c}0.023 \\
(0.029)\end{array}$ \\
\hline Sample Size & 755 & 311 & 444 & \\
\hline
\end{tabular}

Notes: ${ }^{* * *} p<0.01,{ }^{* *} p<0.05,{ }^{*} p<0.10$. Standard deviations reported in Columns 1, 2, and 3. Standard errors reported in Column 4. 
Table 2: Randomization

\begin{tabular}{|c|c|c|c|c|}
\hline & $\begin{array}{c}\text { Bronze } \\
\text { (1) }\end{array}$ & $\begin{array}{l}\text { Silver } \\
\text { (2) }\end{array}$ & $\begin{array}{l}\text { Gold } \\
\text { (3) }\end{array}$ & $\begin{array}{c}\text { Equality of Means } \\
(p-\text { value }) \\
(4)\end{array}$ \\
\hline Take-up rate & $\begin{array}{l}0.013 \\
(0.11)\end{array}$ & $\begin{array}{l}0.054 \\
(0.22)\end{array}$ & $\begin{array}{l}0.181 \\
(0.38)\end{array}$ & 0.00 \\
\hline Objective measure of spoken English: Poor & $\begin{array}{l}0.338 \\
(0.476)\end{array}$ & $\begin{array}{c}0.389 \\
(0.489)\end{array}$ & $\begin{array}{c}0.440 \\
(0.498)\end{array}$ & 0.11 \\
\hline Objective measure of spoken English: Average & $\begin{array}{c}0.481 \\
(0.503)\end{array}$ & $\begin{array}{l}0.400 \\
(0.491)\end{array}$ & $\begin{array}{c}0.357 \\
(0.480)\end{array}$ & $0.07 *$ \\
\hline Objective measure of spoken English: Good & $\begin{array}{c}0.182 \\
(0.388)\end{array}$ & $\begin{array}{c}0.211 \\
(0.409)\end{array}$ & $\begin{array}{c}0.203 \\
(0.404)\end{array}$ & 0.78 \\
\hline Self-reported measure of spoken English: Poor & $\begin{array}{c}0.065 \\
(0.248)\end{array}$ & $\begin{array}{c}0.049 \\
(0.216)\end{array}$ & $\begin{array}{c}0.060 \\
(0.239)\end{array}$ & 0.97 \\
\hline Self-reported measure of spoken English: Average & $\begin{array}{c}0.377 \\
(0.488)\end{array}$ & $\begin{array}{l}0.378 \\
(0.486)\end{array}$ & $\begin{array}{c}0.412 \\
(0.494)\end{array}$ & 0.51 \\
\hline Self-reported measure of spoken English: Good & $\begin{array}{c}0.558 \\
(0.500)\end{array}$ & $\begin{array}{l}0.573 \\
(0.496)\end{array}$ & $\begin{array}{c}0.527 \\
(0.501)\end{array}$ & 0.50 \\
\hline Enrolled in spoken English school before & $\begin{array}{c}0.104 \\
(0.307)\end{array}$ & $\begin{array}{c}0.097 \\
(0.297)\end{array}$ & $\begin{array}{c}0.099 \\
(0.299)\end{array}$ & 0.93 \\
\hline $\begin{array}{l}\text { Inconsistency between self-reported and objective } \\
\text { measures of spoken English }\end{array}$ & $\begin{array}{l}0.103 \\
(0.307)\end{array}$ & $\begin{array}{c}0.702 \\
(0.458)\end{array}$ & $\begin{array}{c}0.747 \\
(0.435)\end{array}$ & 0.67 \\
\hline Mother tongue: Hindi & $\begin{array}{c}0.130 \\
(0.338)\end{array}$ & $\begin{array}{c}0.124 \\
(0.331)\end{array}$ & $\begin{array}{c}0.093 \\
(0.292)\end{array}$ & 0.30 \\
\hline Mother tongue: Telugu & $\begin{array}{c}0.597 \\
(0.494)\end{array}$ & $\begin{array}{c}0.638 \\
(0.482)\end{array}$ & $\begin{array}{c}0.632 \\
(0.484)\end{array}$ & 0.69 \\
\hline Mother tongue: Urdu & $\begin{array}{c}0.078 \\
(0.270)\end{array}$ & $\begin{array}{c}0.108 \\
(0.311)\end{array}$ & $\begin{array}{c}0.082 \\
(0.276)\end{array}$ & 0.84 \\
\hline Distance from college to nearest Veta center in $\mathrm{km}$ & $\begin{array}{c}4.416 \\
(4.411)\end{array}$ & $\begin{array}{c}4.559 \\
(3.972)\end{array}$ & $\begin{array}{c}5.357 \\
(4.815)\end{array}$ & $0.07 *$ \\
\hline Distance from home to nearest Veta center in $\mathrm{km}$ & $\begin{array}{c}5.486 \\
(3.904)\end{array}$ & $\begin{array}{c}4.474 \\
(3.274)\end{array}$ & $\begin{array}{c}5.163 \\
(4.518)\end{array}$ & 0.96 \\
\hline Male & $\begin{array}{c}0.442 \\
(0.500)\end{array}$ & $\begin{array}{c}0.481 \\
(0.501)\end{array}$ & $\begin{array}{c}0.516 \\
(0.501)\end{array}$ & 0.25 \\
\hline Age & $\begin{array}{l}20.250 \\
(0.845)\end{array}$ & $\begin{array}{l}20.230 \\
(1.269)\end{array}$ & $\begin{array}{l}20.500 \\
(3.055)\end{array}$ & 0.24 \\
\hline $\mathrm{SC} / \mathrm{ST}$ & $\begin{array}{c}0.078 \\
(0.270)\end{array}$ & $\begin{array}{c}0.081 \\
(0.274)\end{array}$ & $\begin{array}{c}0.104 \\
(0.307)\end{array}$ & 0.42 \\
\hline $\mathrm{OBC}$ & $\begin{array}{c}0.403 \\
(0.494)\end{array}$ & $\begin{array}{c}0.341 \\
(0.475)\end{array}$ & $\begin{array}{c}0.335 \\
(0.473)\end{array}$ & 0.37 \\
\hline Hindu & $\begin{array}{c}0.857 \\
(0.352)\end{array}$ & $\begin{array}{c}0.816 \\
(0.388)\end{array}$ & $\begin{array}{c}0.868 \\
(0.339)\end{array}$ & 0.50 \\
\hline Household size & $\begin{array}{c}4.506 \\
(1.096)\end{array}$ & $\begin{array}{c}4.476 \\
(1.471)\end{array}$ & $\begin{array}{c}4.626 \\
(1.306)\end{array}$ & 0.33 \\
\hline Degree: B.Sc & $\begin{array}{c}0.260 \\
(0.441)\end{array}$ & $\begin{array}{c}0.357 \\
(0.480)\end{array}$ & $\begin{array}{c}0.242 \\
(0.429)\end{array}$ & 0.28 \\
\hline Degree: B.Com & $\begin{array}{c}0.519 \\
(0.503)\end{array}$ & $\begin{array}{c}0.503 \\
(0.501)\end{array}$ & $\begin{array}{c}0.505 \\
(0.501)\end{array}$ & 0.88 \\
\hline Sample Size & 77 & 185 & 182 & $(0.71)^{\dagger}$ \\
\hline
\end{tabular}

Notes: Columns 1-3 capture treatment (gold, silver, and bronze) specific means and corresponding standard deviations. Standard deviations reported in Columns 1-3. In Column 4, we report $p-$ values from ordered probit regressions of subsidy ( $=2$ if gold, $=1$ if silver, $=0$ if bronze) on each of the covariates separately. ${ }^{* * *} p<0.01,{ }^{* *} p<0.05,{ }^{*} p<0.10$. ${ }^{\dagger}$ : this is the p-value obtained from an ordered probit regression of subsidy on all covariates reported in Panels B-E. 
Table 3: Determinants of Voucher Take-up

\begin{tabular}{|c|c|c|c|c|c|}
\hline & $\begin{array}{c}\text { Take-up } \\
\text { (1) }\end{array}$ & $\begin{array}{c}\text { Take-up } \\
\text { (2) }\end{array}$ & $\begin{array}{c}\text { Take-up } \\
\text { (3) }\end{array}$ & $\begin{array}{c}\text { Take-up } \\
(4)\end{array}$ & $\begin{array}{c}\text { Take-up } \\
(5)\end{array}$ \\
\hline Gold & $\begin{array}{c}0.233 * * * \\
(0.076)\end{array}$ & $\begin{array}{c}0.223 * * * \\
(0.071)\end{array}$ & $\begin{array}{c}0.231 * * * \\
(0.071)\end{array}$ & $\begin{array}{c}0.218 * * * \\
(0.068)\end{array}$ & $\begin{array}{c}0.224 * * * \\
(0.066)\end{array}$ \\
\hline Silver & $\begin{array}{c}0.097 \\
(0.067)\end{array}$ & $\begin{array}{c}0.083 \\
(0.063)\end{array}$ & $\begin{array}{c}0.092 \\
(0.062)\end{array}$ & $\begin{array}{c}0.083 \\
(0.057)\end{array}$ & $\begin{array}{c}0.086 \\
(0.054)\end{array}$ \\
\hline Distance from college to nearest Veta center in $\mathrm{km}$ & & & $\begin{array}{c}-0.007 * * \\
(0.004)\end{array}$ & $\begin{array}{c}-0.007 * * \\
(0.003)\end{array}$ & $\begin{array}{l}-0.006^{*} \\
(0.003)\end{array}$ \\
\hline Distance from home to nearest Veta center in $\mathrm{km}$ & & & $\begin{array}{c}0.003 \\
(0.003)\end{array}$ & $\begin{array}{c}0.002 \\
(0.002)\end{array}$ & $\begin{array}{c}0.002 \\
(0.002)\end{array}$ \\
\hline Objective measure of spoken English: Good & & & & $\begin{array}{c}-0.058 * * * \\
(0.021)\end{array}$ & $\begin{array}{c}-0.054 * * * \\
(0.020)\end{array}$ \\
\hline Objective measure of spoken English: Average & & & & $\begin{array}{l}-0.027 \\
(0.024)\end{array}$ & $\begin{array}{l}-0.027 \\
(0.023)\end{array}$ \\
\hline Self-reported measure of spoken English: Good & & & & $\begin{array}{c}0.038 \\
(0.050)\end{array}$ & $\begin{array}{c}0.035 \\
(0.047)\end{array}$ \\
\hline Self-reported measure of spoken English: Average & & & & $\begin{array}{c}0.037 \\
(0.062)\end{array}$ & $\begin{array}{c}0.042 \\
(0.060)\end{array}$ \\
\hline Self-reported and objective measures of spoken English inconsistent & & & & $\begin{array}{l}-0.025 \\
(0.034)\end{array}$ & $\begin{array}{l}-0.028 \\
(0.034)\end{array}$ \\
\hline Enrolled in spoken English school before & & & & $\begin{array}{l}-0.033 \\
(0.025)\end{array}$ & $\begin{array}{l}-0.037^{*} \\
(0.020)\end{array}$ \\
\hline Mother tongue: Telugu & & & & & $\begin{array}{l}-0.025 \\
(0.027)\end{array}$ \\
\hline Mother tongue: Hindi & & & & & $\begin{array}{c}0.007 \\
(0.037)\end{array}$ \\
\hline Mother tongue: Urdu & & & & & $\begin{array}{c}-0.050 * * \\
(0.023)\end{array}$ \\
\hline Degree: B.Sc. & & $\begin{array}{c}0.146^{* *} \\
(0.067)\end{array}$ & $\begin{array}{c}0.080 \\
(0.066)\end{array}$ & $\begin{array}{c}0.058 \\
(0.061)\end{array}$ & $\begin{array}{c}0.057 \\
(0.061)\end{array}$ \\
\hline Degree: B.Com. & & $\begin{array}{l}0.074 * \\
(0.040)\end{array}$ & $\begin{array}{c}0.026 \\
(0.046)\end{array}$ & $\begin{array}{c}0.015 \\
(0.044)\end{array}$ & $\begin{array}{c}0.017 \\
(0.043)\end{array}$ \\
\hline Male dummy & & $\begin{array}{c}0.027 \\
(0.023)\end{array}$ & $\begin{array}{c}0.021 \\
(0.022)\end{array}$ & $\begin{array}{c}0.012 \\
(0.020)\end{array}$ & $\begin{array}{c}0.015 \\
(0.020)\end{array}$ \\
\hline Age in years & & $\begin{array}{c}0.005 \\
(0.005)\end{array}$ & $\begin{array}{c}0.005 \\
(0.004)\end{array}$ & $\begin{array}{c}0.005 \\
(0.004)\end{array}$ & $\begin{array}{c}0.004 \\
(0.004)\end{array}$ \\
\hline SC-ST & & $\begin{array}{l}-0.014 \\
(0.034)\end{array}$ & $\begin{array}{l}-0.015 \\
(0.032)\end{array}$ & $\begin{array}{l}-0.007 \\
(0.032)\end{array}$ & $\begin{array}{l}-0.003 \\
(0.033)\end{array}$ \\
\hline $\mathrm{OBC}$ & & $\begin{array}{c}0.014 \\
(0.027)\end{array}$ & $\begin{array}{c}0.015 \\
(0.026)\end{array}$ & $\begin{array}{c}0.017 \\
(0.025)\end{array}$ & $\begin{array}{c}0.015 \\
(0.024)\end{array}$ \\
\hline Hindu & & $\begin{array}{l}-0.002 \\
(0.036)\end{array}$ & $\begin{array}{c}0.003 \\
(0.032)\end{array}$ & $\begin{array}{c}0.001 \\
(0.031)\end{array}$ & $\begin{array}{l}-0.023 \\
(0.051)\end{array}$ \\
\hline Household size & & $\begin{array}{c}0.008 \\
(0.007)\end{array}$ & $\begin{array}{c}0.006 \\
(0.007)\end{array}$ & $\begin{array}{c}0.005 \\
(0.006)\end{array}$ & $\begin{array}{c}0.005 \\
(0.006)\end{array}$ \\
\hline $\begin{array}{l}\text { Null: Gold=Silver }{ }^{\dagger} \\
\text { (p-value) }\end{array}$ & $\begin{array}{c}13.95 * * * \\
(0.00)\end{array}$ & $\begin{array}{c}16.14 * * * \\
(0.00)\end{array}$ & $\begin{array}{c}16.10 * * * \\
(0.00)\end{array}$ & $\begin{array}{c}16.94 * * * \\
(0.00)\end{array}$ & $\begin{array}{c}18.27 * * * \\
(0.00)\end{array}$ \\
\hline Sample Size & 444 & 444 & 444 & 444 & 444 \\
\hline
\end{tabular}

Notes: Marginal Effects from Probit Regression. Robust standard errors in parenthesis. ${ }^{* * *} p<0.01,{ }^{* *} p<0.05,{ }^{*} p<0.1$. †: Chi-square test results testing equality between the Gold and Silver coefficients. 